\title{
Teaching Speaking Through Public Speaking Course SHAMPA IFTAKHAR
}

\begin{abstract}
In Bangladesh, English is taught as a foreign language. The English Language Teaching Improvement Project (ELTIP) introduced commutative textbooks in between 1992 to 2001 from class three to the higher secondary level. The main aim of ELTIP is to facilitate the teaching and learning of English with a methodology that will encourage students to acquire communicative competence in English through regular practice of these skills. Each of the books contains many tasks on speaking, but unfortunately in reality there is no practice and reflection of this skill. The speaking skill is never examined in S.S.C. and H.S.C. exam though in the English medium schools the scenario is totally opposite. Now the students who get admitted in the private universities having a very poor competency in speaking face great problems from the very beginning because English is the medium of instruction in these universities and general English courses are compulsory for all students. Very few students are capable of understanding lectures given in English. So conducting the class in English becomes a great challenge for all teachers. In my paper, I intend to analyse some factors that are closely related with teaching speaking. Then I will try to evaluate how Public Speaking course at Stamford University Bangladesh plays a vital role in teaching speaking, and our teachers' and learners' opinions regarding this course.
\end{abstract}

\section{Introduction:}

The aim of Communicative Language Teaching is to develop students' communicative competence by engaging them in meaningful interaction. Students' ability to speak in English accurately and fluently ensures their communicative competence in English. Speaking is one of the primary skills which is developed very naturally. But teaching speaking, no matter what language it might be, is not a very easy task. No doubt, mastering the art of speaking is the most important aspect of learning a second or foreign 
language and success is measured in terms of the ability to carry out a conversation in that target language. As speaking is the most naturally accomplished of language feats, teaching speaking could be an opportunity, at the same time, it could be a threat. It gives us the chance to broaden the scope of and opportunity for speaking activities. On the other hand, teaching speaking demands us to teach and reinforce "correct" spoken language, rectifying habitual errors of speech. The former suggests an enlightened opportunity; the latter, is more of a threat.

\section{What is speaking?}

According to Huebner (1960), "Speaking is a skill used by someone in daily life communication by much repetition; it primarily a neuromuscular and not an intellectual process. It consists of competence in sending and receiving messages" (p. 5). In psycholinguistic, speaking is a productive language skill.

\subsection{Elements of good practice in speaking:}

For good English teaching, in his book, The Literate Imagination (1994), Harrison offers us a useful summary of the nature of oral English teaching. He mentions that learners need confidence and expertise in talk so that they can:

- listen to, convey and share ideas and feeling

- listen to, convey and share information

- understand, convey and share the story of their own or others

- listen to, present defend and interrogate points of view;

- consider questions, raise questions, work towards answers;

- understand accounts of processes, be able to describe and evaluate processes;

- be sensitive(as listener and as speaker) to appropriate tone and rhythms of voice - for example, sometimes reflective and exploratory, at other times assertive and persuasive;

- be aware (as listener and as speaker) of the need for clear expression; 
- know when to be tolerant, when to support and when to challenge in talk with others;

- be confident in providing a personal presence in talking, without letting self-consciousness intrude on what you want to say - and accept the personal presence of others, while respecting what they have to say (rather than how they say it). (p.135)

This list reflects a holistic and exhaustive view of the nature of speaking and listening in the English classroom with both subtlety and rigour.

\subsection{Role of the Audience:}

The role of audience for talk is a vital one. It is an active role too, for the audience provides the other half of the speaking and listening combination. To fulfil the full range of oral possibilities alluded to above, pupils should be given every opportunity to experience a variety of audience involving:

- their classmates, as a whole class or as individuals or small groups;

- other pupils of different ages and interests;

- pupils from different schools, particularly cross-phase partnership schools;

- teachers-and not only their English teacher, if feasible opportunities can be found;

- other adults from different walks of life with particularly relevant interests;

- imagined audiences through role-play and media-based oral projects;

- real audiences through the media of audio-and video-taping; and even, as the facility becomes more widely available, videoconferencing.

\subsection{Role of the Teacher:}

In teaching speaking, the English teacher's own role is crucial. Harmer (2001), in his book, The Practice of English Language Teaching, points out three different roles that the teacher needs to play to get students speak fluently. 


\subsubsection{Prompter:}

Sometimes while speaking student might get lost i.e. they are not able to say what to say next. "Sometimes, when students are involved in a roleplay activity, for example, they lose the thread of what is going on, or they are 'lost for words' (i.e. they might still have the thread but be unable to proceed productively for lack of vocabulary). They may not be quite sure how to proceed." (Harmer, 2001, p. 60). In such situation, it is very natural that the teacher wants to help the students. However, as the teacher is very keen to encourage the students to think creatively rather than have them hang on teacher's every word, he or she does not want to take charge. Thus a teacher occasionally offers words or phrases suggesting what might come next.

Interestingly, in this situation students prefer to use mother-tongue. But the teacher has to prompt him or her in monolingual groups to speak in English. When the teacher prompts, she or he needs to do it 'sensitively and encouragingly'. Then the student will able to overcome their nervousness.

\subsubsection{Participant:}

When the students present a speech through group-discussion or roleplay, the teacher traditionally listens to them carefully. At the end of the activity, the teacher gives feedback. But at times a teacher also participates in these activities. Harmer (2001) mentions that by participating the teachers 'can prompt covertly, introduce new information to help the activity along, ensure continuing student engagement, and generally maintain a creative atmosphere' (p.276). Here, a teacher should not participate too much as he or she might dominate the speaking and the whole class might give full concentration to that teacher's speaking.

\subsubsection{Feedback Provider:}

The teacher should give feedback in his students' speaking activities. In this regard, the teacher must avoid over-correction. A helpful and gentle 
correction can make the students confident and it 'may get students out of difficult misunderstanding and hesitations' (Harmer, 1997, p. 276). The methodologist Lynch (1997) argues that the students learn many things from the problems that they face while speaking. The teacher can provide them with some of the words or phrases necessary to help them negotiate a way out of their communicative impasses. The success of a teacher as a feedback provider depends on how and when feedback is given. When teachers get involved, not only to correct but also to supply alternative modes of expression to help students, they remove the need to negotiate meaning, and thus they may deny students a learning opportunity. Although in such situations teacher's involvement may sometimes be necessary, it is unfortunate too. In Lynch's (1997) words, "the best answer is to the question of when to intervene in learner talk is: as late as possible" (p. 324). In short, the success of the teacher's role as a feedback provider depends on his or her tact and the appropriateness of the feedback we give in the particular speaking activities.

\subsection{Learners' Safeguards:}

Harrison (1994) recommends the following safeguards on behalf of the learners:

- Encourage flexibility among all speakers, in mediating between non-standard (usually colloquial) and standard (usually written) forms of mother tongue.

- Empower all speakers to range over the whole universe of discourse-intellectual and affective

- Encourage a full sense of ownership of all the versions of language that may be required by speakers

- Instil confidence in the use of these versions of language

- Encourage respect for the variant versions of language that may be used by other individuals and other communities, for their particular needs. (p. 239) 


\subsection{Relation between Speaking and Listening:}

An English teacher encourages the students and gives stimulation to speak in the classroom. Here the relation between listening and speaking is a vital issue. A teacher must listen very attentively and sympathetically as this kind of attentive and sympathetic listening is the key to a great deal of effective speaking teaching. An English teacher should guide the students that speaking should be spontaneous, no matter on what topic they are talking. Regarding this, a teacher can actively encourage the drafting of the oral work. Lucas (2001) also supports this view and suggests that preparation is must for speaking activities. Though learning to speak is largely a natural process, the English teacher needs to understand that oral drafting may well be most apt in different types of planned performance, and the potential and power of the voice to celebrate and accomplish should never be under-estimated or under-taught. Students might consider the following facts in their oral draft:

- alteration and adaptation of the spoken content;

- increased sophistication of delivery

- greater awareness of the specific audience in mind;

- the objective of speaking activities, i.e. whether they take part in speaking to inform, to persuade or to entertain.

\subsection{Speaking Activities:}

Development of speaking activities requires the use of some activities which can be categorized in three most commonly used organizational forms: Whole-class teaching, Group -work and Pair work.

\subsubsection{Whole-class teaching:}

In a research, Richards and Lockhart (1999) mentions that in whole-class teaching the teacher leads the whole-class through a learning task. Harmer (1992) named the whole-class teaching as 'lockstep method' and mentions, 
"Lockstep is the class grouping where all the students are working with the teacher, where all the students are 'locked into' the same rhythm and pace, the same activity ... where a teacher-controlled session is taking place" ( $p$. 243).

\subsubsection{Group-work:}

In group work, the teacher divides the class into small groups to work together (usually four or five students in each group). "As in pair work, all the groups work at the same time" (Doff, 1991, p. 138). Ur (1991) agrees that group work provides some learners with confidence and courage. "Students who are shy of speaking in front of the whole class, or to the teacher, often find it much easier to express themselves in front of a small group of their peers" ( Ur, 1991, p.7). Richards and Lockhart (1999) say that group work is likely to increase the amount of student participation in the class and promote collaboration among learners. Here learners' role is more active and the teacher cannot dominate the class.

\subsubsection{Pair work:}

"In pair work, the teacher divides the whole class into pairs. Every student works with his or her partner, and all the pairs work at the same time" (Byrne, 1991, p. 137). Byrne (1991) finds that this speaking activity facilitates learners' independence. He considers pair work as an interaction similar to real-life language use. "They [learners] can face and talk directly to one another, so it is much closer to the way we [people] use language outside the classroom." (Byrne, 1991, p. 31)

\section{3. 'Public Speaking' Course:}

At Stamford University Bangladesh, 'Public Speaking' course is offered where students are prepared to give speeches in the class. In the course outline it is mentioned that this course is primarily designed to provide both theory and the opportunity for understanding and improving 
communication skills in public and professional speaking situations. The objectives of this course are:

- To become an informed consumer and critic of public speaking messages

- To gain an understanding of the theory and underlying principles of effective public speaking

- To gain an understanding of the importance of the techniques for adapting messages to a variety of audience and occasions

- To demonstrate an ability to prepare and deliver effective speeches

- To improve skills in critical listening and thinking

In brief, we can say this course will help the student to be a good and fluent speaker and presenter,

- by producing the English speech sounds and sounds patterns,

- by organizing their thoughts in a meaningful and logical sequence quickly and confidently with some appropriate words and sentences according to the proper social setting, audience, situation and subject matter.

In 'Public Speaking', all the above mentioned speaking activities are used. At Stamford, students are supposed to prepare and present Self introductory, Impromptu, Role Play, Informative and Persuasive speech.

\section{Methodology:}

This study focused on the two aspects of teaching speaking through Public speaking course in the class. One aspect is how far this course is helpful and what are the basic challenges our teachers face in this course. Another one is the students' response to the speaking class and different presentations though their speaking skill is never justified or tested before.

This study followed 'Typical Case Sampling' which is a type of purposive sampling, suggested by Wiersma \& Jurs (2005) in their book Research Methods in Education: An Introduction. 
I collected my data from March 2012 to first week of July 2012. The participants were teachers and students of Stamford University. The interviews were conducted with six teachers: four females and two males. All of them are university graduate and at present they are taking 'Public Speaking' course in different programs. They were assigned to conduct the same course previously. Three of respective teachers are from Jahangir Nagar University, two from Dhaka University and one from National University. They have been teaching at Stamford University for more than 4 years, i.e. they are all experienced. All the names of the participants are kept anonymous as it may raise ethical questions.

35 students were selected from the Department of Law and Journalism, 15 students from Journalism and 20 students from Law. They were all in the same age group. They completed their S.S.C. and H.S.C. from the different schools of Dhaka, Khulna, Barisal and Chittagong. Before taking 'Public Speaking', they completed 'English Fundamental' and 'English Composition'.

In this study, data were collected through interviews, observations and documents analysis. The interviews followed 'structured' format where detailed one-to one interview of the students and teachers were conducted. In total, 35 students and 6 teachers were interviewed. There were interview questions out the facts as well as the attitudes and opinions of students and teachers. There were different interview questions for teachers and students (See Appendix A, B).

The second tool that was used for the study was observation. A total of 36 classes were observed in the department of Law and Journalism to find out the basic problems in speaking and also to examine the specific facilities provided by the university. Students' comments and attitudes as an audience were also observed keenly at the time when their classmates presenting a speech in a group or alone. Some documents, such as, course outline and examination questions were also examined. 


\section{Findings:}

From the teachers' and students' points of views the findings are noted. Their salient opinions regarding teaching speaking through Public Speaking course can be divided in two categories. Moreover some of the findings are noted after observing the classes and analysing the documents. These are described below.

\subsection{Teachers' Perspective:}

Our teachers agree that students should talk most in the speaking class. But in reality, teachers have to talk most of the time to describe theories or chapters from the required text books on Public Speaking.

Our students are not confident and feel shy to talk. It is true that they are not fluent and at the same time, they can understand that they make many mistakes in almost all components of speaking i.e. grammar, vocabulary, accent, and pronunciation. Interestingly, when talking in English, despite these problems, they care for perfection. In such cases, when a teacher points out the basic problems in their speaking, they prefer to keep silent rather than talking.

Four of our teachers mention that our students' level of English language differs from department to department. For example, they agree the students of English department can easily express anything in English. At least, they are not nervous while speaking. Their level of English language is also better. Basically, students of Civil, Computer Science and Engineering, EEE, Pharmacy, Microbiology, and Journalism have a good command over English language whereas students of LLB, Film and Media are comparatively weak. Some BBA batches were excellent but most of cases they were average. Two teachers pointed out that the level of English language is average in all departments.

All of our participants agree that Public Speaking course is very helpful to overcome students' basic problems in speaking skill. Here students' 
outlook to Public Speaking course is noteworthy. In most of the cases, they consider this course as a language course like English Fundamental or Composition. Moreover, they have no ideas or experiences in speaking before an audience. So when they are exposed to a speaking class, they usually take 1 to 2 months to cope up with the new context. By this time, Mid-term examinations knock, and they get confused and are concerned more about passing exams. The problem becomes more complicated in case of other departments where faculties, along with the students, treat this course as a language course.

Students' single classroom presentation on 'Self-Introductory' and group presentation on 'Delivery' were examined. Various problems in the field of grammar, fluency, pronunciation, vocabulary, posture, and logical development of the ideas were identified.

The teachers agree that large class is a big a problem for an effective public speaking class. At Stamford, our teachers meet the public speaking class containing 30-35 students in average. But two classes in a week are not enough to describe the theories and to take presentation of a large class. Here, the duration of class is 1 hour and 15 minutes. Within this time, a teacher is supposed to perform some other routine works such as, roll call, answering different enquiries. So if in a presentation class, a student is given 5 minutes for speaking, a teacher needs 5 minutes more for questionanswer session and feedback. Ultimately, a total of 22 classes is not enough for this course. Moreover, the students are not categorized according to their level of English knowledge.

Two teachers find no problem in course design. The course design is thoughtful and effective. Four teachers find the course design faulty and they feel there is a scope to develop it. Taking six presentations is really a tough job. To one teacher the title 'Public Speaking' is a problem. Our students' background is very poor so they can not digest the title. Besides, all they need is spoken English, informal discussion with pair-work and 
group discussion. But here the title sounds very formal and it is really intimidating for them.

Regarding the physical setting of the class room, our participants find no problem. In every classroom, tables and chairs are arranged in rows. As the furniture are not fixed to the floor, they could be easily moved and arranged in group work, pair work or in face-to- face interaction. But logistic supports are very poor here. Sometimes multimedia, speaker, and OHP (Over Head Projector) are not available. In addition, interference occurs frequently for load-shedding.

All participants encourage students in many ways to develop their speaking skill. One teacher suggests them to watch anything that interests them expect English news. The main reasons are: i) they might be unable to relate the news with their ideas and ii) technical languages used in the news might not be understood by them. Most of our teachers suggest to watch Star movies, English Cartoon channel, National Geography without Bangla dabbing and English sub-titles. One teacher suggests to watch Friends in Star World as she thinks it is extremely helpful to improve their spoken English. Another teacher suggests to spend at least one hour per day in speaking English in a group.

Our respective teachers identify the major reasons for students' poor skill in speaking. All teachers agree that speaking is ignored from the primary school; English classes are conducted in Bangla from primary level. Teachers themselves lack an extensive exposure to spoken English. Both students and teachers never require to listen and to speak English much for everyday conversation. More seriously, teachers receive no training before recruitment. One participant also mentions that some of Bangla TV serials have a great impact on students' speaking where directors intentionally use incorrect English with a weird accent and pronunciation. As a viewer, the students' adopt the peculiar accent and pronunciation which is a very common trend within this age group. This tendency, in the long run, 
deteriorates students' proficiency in speaking and the standard of English, too.

To remove the basic problems of speaking, all agree that English classes must be conducted in English from the primary levels. Exam system should be reset so that from S.S.C and H.S.C, students' speaking skill can be assessed. All faculties are suggested to take class in English. Bangla should be avoided even in the counselling hours. Faculties must allow students' to speak freely in English no matter how many mistakes they might make. Then exam scripts of all programs must be checked pointing out all grammatical errors. If errors are pointed out and corrected, the students would be careful in writing next. Consequently, it would help him to avoid mistakes in speaking, too. All officials must use English. In such a way, it would be possible to create a better speaking environment. One participant recommends to introduce an advance course on Public Speaking.

\subsection{Students' Perspective:}

All students agree that they are having the same problem in speaking. While speaking in English, they feel very nervous. They had no previous experience of speaking in English in the class or outside the class in the Secondary and Higher Secondary levels. My students of Journalism mentioned that in their $2^{\text {nd }}$ semester they presented a PowerPoint presentation on Computer Fundamental. There they just read from the slides though the course teacher asked them to discuss the points too. All of them also agree that their vocabulary is so poor that they get confused what to say. They are poor at grammar too. In Secondary and Higher Secondary, they had English as a compulsory subject. Their texts were prescribed from NCTB (National Curriculum Text Board). But the teacher conducted classes in Bangla. Only five students out of fifty (four from different schools of Dhaka and one from Khulna) informed that their English teachers at college conducted English classes in English.

Regarding the problem of Public Speaking course they mentioned that one semester is not enough to develop the speaking skill as this skill was 
never tested before. They need more time to be confident to speak and to present something before an audience with fluency and grammatical accuracy. They also pointed out that their class setting is not at all supportive. Their university building is over market near the main road. Different types of noise bother them in almost every class. In addition, power failure is so frequent that they felt very uncomfortable in an airconditioned room having no windows. Like teachers, they also mentioned logistic support is not very strong at Stamford. Some students demanded to provide loudspeaker or microphone for this course as some used to speak in low voice.

30 students supported the view that Public Speaking course plays a vital role to overcome their problems in speaking. Generally, they are not motivated to speak freely in English, but this course aims to make them good speakers. Teachers encourage and motivate them to speak, ignoring the basic problems. When they prepared their speech, they could contact the respective teacher during the counselling hours to find out the flaws that still remained. Teachers also helped them by providing a word or phrase in the time of presentation if they forgot what to say. After the final presentation, teachers gave feedback, identified problems and suggested what to do for betterment. This course made them more confident as they got chances to speak on different topics.

27 students mentioned that in the beginning they treated this course as a language course. But after few classes they understood to attain a good grade, they must be good presenters. So they practised speaking in English at home. During the theory classes, they tried to ask questions in English.

30 students mentioned their class-mates never played a supportive role as audience. They never liked to listen to their friends' presentations with patience. As soon as one finished his or her presentation, he or she got busy talking with others, or got out of the room for different purpose. Though teachers guided them not to go out and listen to the speech carefully, many students just ignored the advice. 


\section{Suggestions:}

Public Speaking course, no doubt, gives our learners an opportunity to speak in English. For a successful speaking activity in this course we should concern the following issues:

\subsection{High Motivation:}

We should motivate our students so that they talk a lot inside and outside the classroom. Ur (1996) supports this view. To motivate the learner, teachers must welcome meaningful noise of the interaction in the speaking class. Chambers (1999) claims that our learners are 'image conscious teenagers" (p. 127) who are alert not to make mistake in speaking, so they keep silent. To reduce their anxiety, the English teacher should select and sequence speaking activities thoughtfully. Indeed, if learners are not encouraged to take risks with their speaking, the teacher needs to promote a classroom environment in which errors are regarded as a part of the learning process and the teacher should correct those errors with sensibility.

\subsection{Managing the large-class:}

Though for a successful speaking activity, moderate class size is desirable, our teachers meet large classes with mixed ability students. Harmer (2007) mentions "in a large class, good class feeling is warmer and more enveloping than it is in a small group" (p. 127). So the best thing is to manage the large class with most thoughtful speaking activity that can confirm the best output from a speaking task.

\subsection{Administrative Policy:}

University policy must be moderated to ensure better English speaking environment. No officials should use Bangla in the office premises. In that case, learners might have a little scope to use the mother tongue. Ultimately, they will be expert in using situational language. Then necessary changes in the class-setting should be taken into consideration. 
Speaking class must not lack in logistics. Lastly, all faculties of all departments should securitize the exam-scripts identifying and correcting all errors in English.

\section{Conclusion:}

Public Speaking course at Stamford has broadened a great scope for teaching speaking. Though this is a small scale study, I do believe this paper has tried to point out some important issues related with this course. Risk exists, no doubt, as a single speaking course will never be able to develop learners' speaking skill. However, we can not ignore the possibilities of this course. In this regard, we must update the course-design according to the demand of time. Moreover, trained teachers must be recruited in the secondary and higher secondary levels. 


\section{References}

Byrne, D. (1991). Techniques for Classroom Interaction. Cambridge: Cambridge University Press.

Chambers, G. (1999). Motivating Language Learners. Clevedon: Multilingual Matters Ltd.

Doff, A. (1991). Teaching English. Cambridge: Cambridge University Press.

Harrison, B. (1994). The Literate Imagination. London: David Fulton.

Harmer, J. (1992, 2001, 2007). The Practice of English Language. London: Pearson Longman.

Huebner, T. (1960). Audio Visual Technique in Foreign Language. New York: Cambridge University Press.

Lynch, T. (1997). "Nudge, nudge: teacher interventions in task-based learner talk." ELT Journal, 51(4), 317-325.

Lucas, S. (2001). The Art of Public Speaking (7th ed.). New York: McGrew-Hill Companies.

Richard, C.J. \& Lockhard, C. (1999). Reflective Teaching in Second Language Classroom. Cambridge: Cambridge University Press.

Ur, P. (1991). Discussion that Work. Cambridge: Cambridge University Press.

Ur, P. (1996). Language Teaching: Practice and Theory. Cambridge: Cambridge University Press.

Wiersma, W., \& Jurs, S.G. (2005). Research Methods in Education: An Introduction. Boston: Pearson. 


\section{Appendix A: Interview questions for teachers}

- How long have you been teaching English language at Stamford?

- How many times and with which programs did you conduct classes on Public Speaking?

- How many students are there in every class?

- What are their levels of English language?

- Who should talk most in the speaking class?

- According to you, what are the main reasons for poor skill in speaking?

- Do you think Public Speaking course is helpful to overcome students' basic problems in speaking?

- Mention if there is any problem in the course-design.

- What problems do you face in conducting the speaking class?

- How do you encourage students?

\section{Appendix B: Interview questions for students}

- Have you ever exposed to English speaking class? When?

- What kind of problem do you face while speaking in English?

- How did your teacher conduct English classes in S.S.C and H.S.C?

- Is it a language course like English Fundamental or Composition?

- Do you think Public Speaking course is helpful? How?

- According to you what the basic problems in this course?

- Assess your classmates as audience. 


\section{Appendix C: Observation Checklist:}

1. Department and batch: Law 47-A

Number of students: 46

Class duration: 2 hrs 30mins (back-to back class)

\begin{tabular}{|c|c|c|c|c|c|}
\hline $\begin{array}{l}\text { Class } \\
\text { No }\end{array}$ & Chapter & $\begin{array}{l}\text { Teaching } \\
\text { Technique }\end{array}$ & $\begin{array}{l}\text { Logistic } \\
\text { support }\end{array}$ & $\begin{array}{l}\text { Power } \\
\text { Failure }\end{array}$ & $\begin{array}{l}\text { Students' } \\
\text { Performance }\end{array}$ \\
\hline 1 & $\begin{array}{l}\text { Introductory } \\
\text { Class }\end{array}$ & $\begin{array}{l}\text { Ice-breaking \& } \\
\text { distributing } \\
\text { course outline }\end{array}$ & & 2 times & Good \\
\hline 2 & $\begin{array}{l}\text { Speaking in } \\
\text { Public }\end{array}$ & $\begin{array}{l}\text { Theory Class- } \\
\text { Reading aloud, } \\
\text { explanation }\end{array}$ & $\begin{array}{l}\text { Multi- } \\
\text { media }\end{array}$ & $\begin{array}{l}3 \text { to } 4 \\
\text { times }\end{array}$ & $\begin{array}{l}\text { Good, } \\
\text { feeling shy }\end{array}$ \\
\hline 3 & $\begin{array}{l}\text { Selecting a } \\
\text { Topic and } \\
\text { Purpose }\end{array}$ & $\begin{array}{l}\text { Theory } \\
\text { Class-reading, } \\
\text { explanation and } \\
\text { summary }\end{array}$ & $\begin{array}{l}\text { Multi- } \\
\text { media }\end{array}$ & 4 times & $\begin{array}{l}\text { Unsatisfactory, } \\
\text { poor } \\
\text { understanding }\end{array}$ \\
\hline 4 & $\begin{array}{l}\text { Presentation } \\
\text { on Self- } \\
\text { Introduction }\end{array}$ & $\begin{array}{l}\text { Students' } \\
\text { Individual } \\
\text { Work }\end{array}$ & $\begin{array}{l}\text { Multi- } \\
\text { Media }\end{array}$ & 2 times & $\begin{array}{l}\text { Poor at } \\
\text { pronunciation, } \\
\text { grammar, not } \\
\text { fluent, }\end{array}$ \\
\hline 5 & $\begin{array}{l}\text { Analysing } \\
\text { the Audience }\end{array}$ & $\begin{array}{l}\text { Theory class- } \\
\text { defining, } \\
\text { explanation, } \\
\text { summary }\end{array}$ & $\begin{array}{l}\text { Multi- } \\
\text { media }\end{array}$ & 4 times & $\begin{array}{l}\text { Less attentive, } \\
\text { silently listen the } \\
\text { lectures, no } \\
\text { inquiry }\end{array}$ \\
\hline 6 & $\begin{array}{l}\text { Presentation } \\
\text { on Delivery }\end{array}$ & Group work & $\begin{array}{l}\text { Multi- } \\
\text { media }\end{array}$ & 4 times & $\begin{array}{l}\text { Well-prepared } \\
\text { but poor } \\
\text { performance due } \\
\text { to nervousness, } \\
\text { poor accent, } \\
\text { vocabulary, no } \\
\text { grammatical } \\
\text { accuracy }\end{array}$ \\
\hline
\end{tabular}


2. Department and batch: Law 47-C

Number of students: 44

Class duration: 2 hrs 30mins (back-to back class)

\begin{tabular}{|c|c|c|c|c|c|}
\hline $\begin{array}{l}\text { Class } \\
\text { No }\end{array}$ & Chapter & $\begin{array}{l}\text { Teaching } \\
\text { Technique }\end{array}$ & $\begin{array}{l}\text { Logistic } \\
\text { support }\end{array}$ & $\begin{array}{l}\text { Power } \\
\text { Failure }\end{array}$ & $\begin{array}{c}\text { Students' } \\
\text { Performance }\end{array}$ \\
\hline 1 & $\begin{array}{l}\text { Introductory } \\
\text { Class }\end{array}$ & $\begin{array}{l}\text { Ice-breaking \& } \\
\text { distributing } \\
\text { course outline }\end{array}$ & & 2 times & $\begin{array}{l}\text { Average, } \\
\text { prefers Bangla } \\
\text { while speaking }\end{array}$ \\
\hline 2 & $\begin{array}{l}\text { Speaking in } \\
\text { Public }\end{array}$ & $\begin{array}{l}\text { Theory Class- } \\
\text { Reading aloud, } \\
\text { explanation }\end{array}$ & $\begin{array}{l}\text { Multi- } \\
\text { media }\end{array}$ & $\begin{array}{l}3 \text { to } 4 \\
\text { times }\end{array}$ & $\begin{array}{l}\text { feeling shy, } \\
\text { nervous, poor } \\
\text { in grammar }\end{array}$ \\
\hline 3 & $\begin{array}{l}\text { Selecting a } \\
\text { Topic and } \\
\text { Purpose }\end{array}$ & $\begin{array}{l}\text { Theory } \\
\text { Class-reading, } \\
\text { explanation and } \\
\text { summary }\end{array}$ & $\begin{array}{l}\text { Multi- } \\
\text { media }\end{array}$ & 4 times & $\begin{array}{l}\text { Unsatisfactory, } \\
\text { poor } \\
\text { understanding, } \\
\text { no inquiry }\end{array}$ \\
\hline 4 & $\begin{array}{l}\text { Presentation } \\
\text { on Self- } \\
\text { Introduction }\end{array}$ & $\begin{array}{l}\text { Students' } \\
\text { Individual } \\
\text { Work }\end{array}$ & $\begin{array}{l}\text { Multi- } \\
\text { Media }\end{array}$ & 2 times & $\begin{array}{l}\text { Mixed, } \\
\text { poor in } \\
\text { pronunciation, } \\
\text { grammar, not } \\
\text { fluent, eager to } \\
\text { leave class }\end{array}$ \\
\hline 5 & $\begin{array}{l}\text { Analysing } \\
\text { the Audience }\end{array}$ & $\begin{array}{l}\text { Theory class- } \\
\text { defining, } \\
\text { explanation, } \\
\text { summary }\end{array}$ & $\begin{array}{l}\text { Multi- } \\
\text { media }\end{array}$ & 4 times & $\begin{array}{l}\text { Less attentive, } \\
\text { silently listen } \\
\text { the lectures, no } \\
\text { inquiry }\end{array}$ \\
\hline 6 & $\begin{array}{l}\text { Presentation } \\
\text { on Delivery }\end{array}$ & Group work & $\begin{array}{l}\text { Multi- } \\
\text { media }\end{array}$ & 4 times & $\begin{array}{l}\text { Well-prepared } \\
\text { average } \\
\text { performance, } \\
\text { some showed } \\
\text { improvement }\end{array}$ \\
\hline
\end{tabular}


3. Department and batch: Journalism 46

Number of students: 20

Class duration: 2 hrs 30mins (back-to back class)

\begin{tabular}{|c|c|c|c|c|c|}
\hline $\begin{array}{l}\text { Class } \\
\text { No }\end{array}$ & Chapter & $\begin{array}{l}\text { Teaching } \\
\text { Technique }\end{array}$ & $\begin{array}{l}\text { Logistic } \\
\text { support }\end{array}$ & $\begin{array}{l}\text { Power } \\
\text { Failure }\end{array}$ & $\begin{array}{c}\text { Students' } \\
\text { Performance }\end{array}$ \\
\hline 1 & $\begin{array}{l}\text { Introductory } \\
\text { Class }\end{array}$ & $\begin{array}{l}\text { Ice-breaking \& } \\
\text { distributing } \\
\text { course outline }\end{array}$ & & once & $\begin{array}{l}\text { Active } \\
\text { Listeners, good } \\
\text { understanding }\end{array}$ \\
\hline 2 & $\begin{array}{l}\text { Speaking in } \\
\text { Public }\end{array}$ & $\begin{array}{l}\text { Theory Class- } \\
\text { Reading aloud, } \\
\text { explanation }\end{array}$ & $\begin{array}{l}\text { Multi- } \\
\text { media }\end{array}$ & 3 times & Good \\
\hline 3 & $\begin{array}{l}\text { Selecting a } \\
\text { Topic and } \\
\text { Purpose }\end{array}$ & $\begin{array}{l}\text { Theory } \\
\text { Class-reading, } \\
\text { explanation and } \\
\text { summary }\end{array}$ & $\begin{array}{l}\text { Multi- } \\
\text { media }\end{array}$ & 4 times & Satisfactory \\
\hline 4 & $\begin{array}{l}\text { Presentation } \\
\text { on Self- } \\
\text { Introduction }\end{array}$ & $\begin{array}{l}\text { Students' } \\
\text { Individual } \\
\text { Work }\end{array}$ & $\begin{array}{l}\text { Multi- } \\
\text { Media }\end{array}$ & 2 times & $\begin{array}{l}\text { Well prepared, } \\
\text { but nervous }\end{array}$ \\
\hline 5 & $\begin{array}{l}\text { Analysing } \\
\text { the Audience }\end{array}$ & $\begin{array}{l}\text { Theory class- } \\
\text { defining, } \\
\text { explanation, } \\
\text { summary }\end{array}$ & $\begin{array}{l}\text { Multi- } \\
\text { media }\end{array}$ & 2 times & Satisfactory \\
\hline 6 & $\begin{array}{l}\text { Presentation } \\
\text { on Delivery }\end{array}$ & Group work & $\begin{array}{l}\text { Multi- } \\
\text { media }\end{array}$ & 3 times & $\begin{array}{l}\text { Well prepared, } \\
\text { showed } \\
\text { improvement in } \\
\text { grammar, } \\
\text { vocabulary and } \\
\text { accent }\end{array}$ \\
\hline
\end{tabular}

